\title{
Complete Classification of Simple Current Automorphisms
}

B. Gato-Rivera*

and

\author{
A. N. Schellekens
}

CERN, 1211 Geneva 23, Switzerland

\begin{abstract}
The complete classification of all fusion rule automorphisms within simple current orbits is presented.
\end{abstract}

$\star$ On leave of absence from "Instituto de Física. Fundamental", Madrid. 

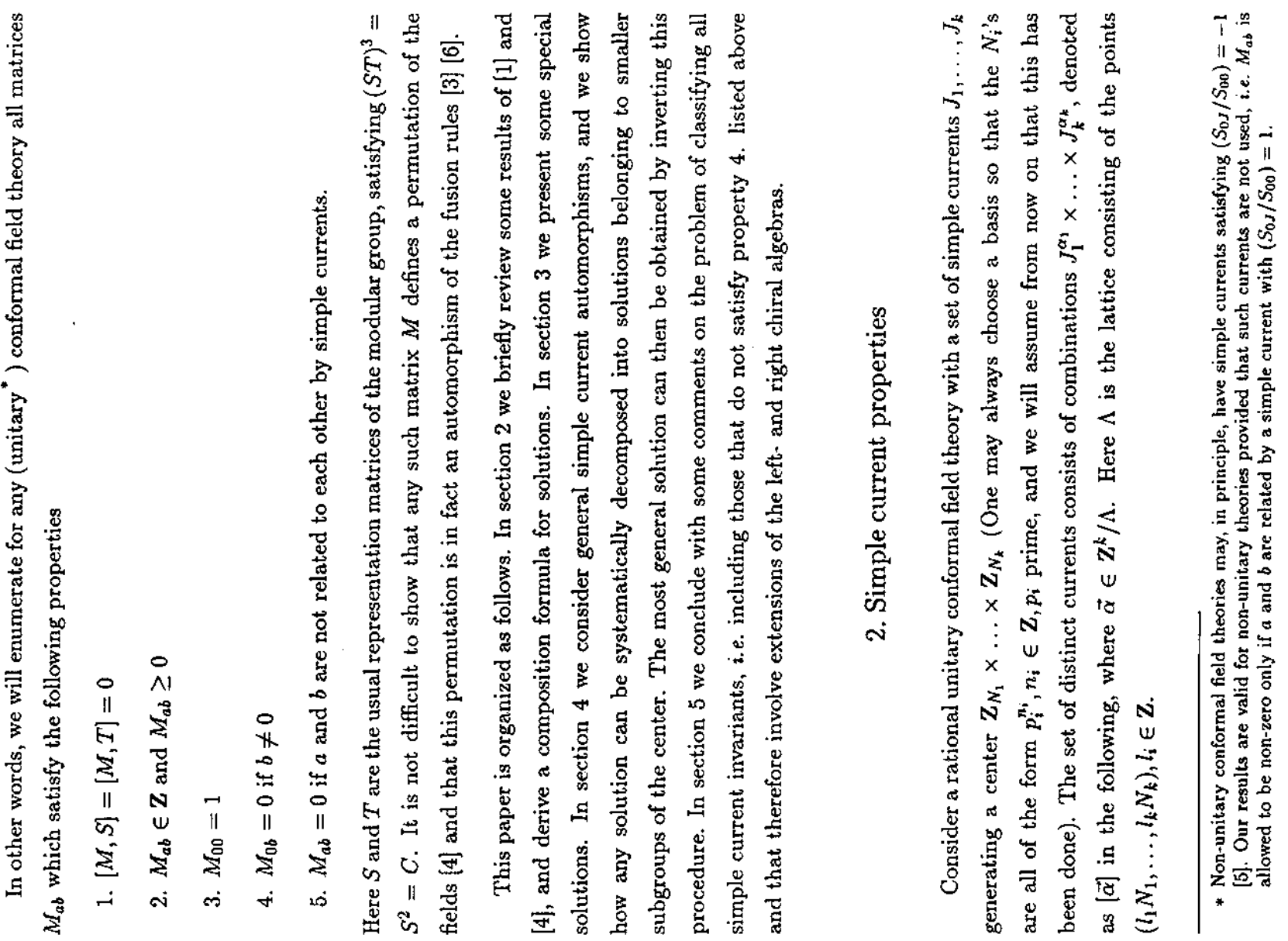

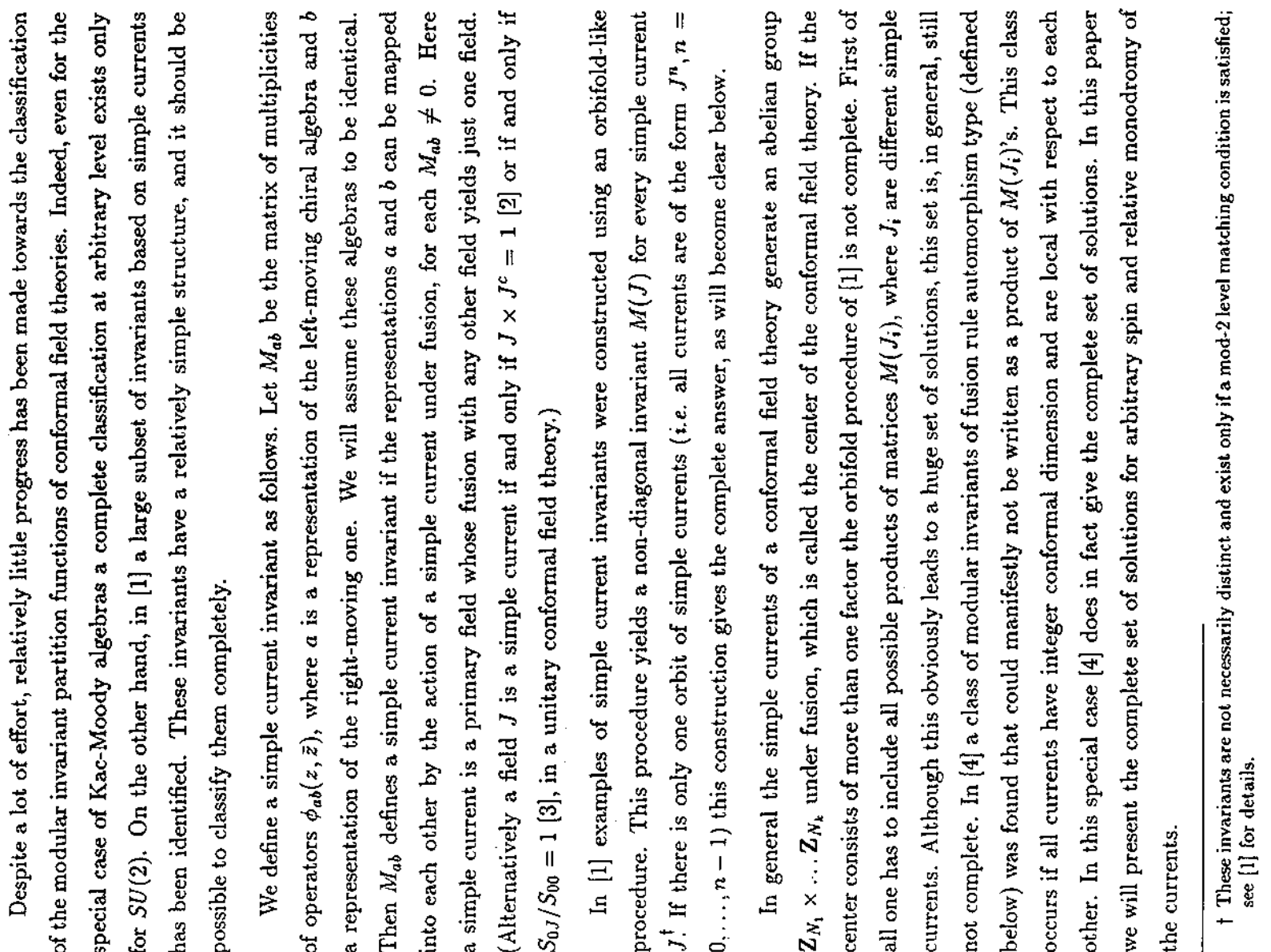



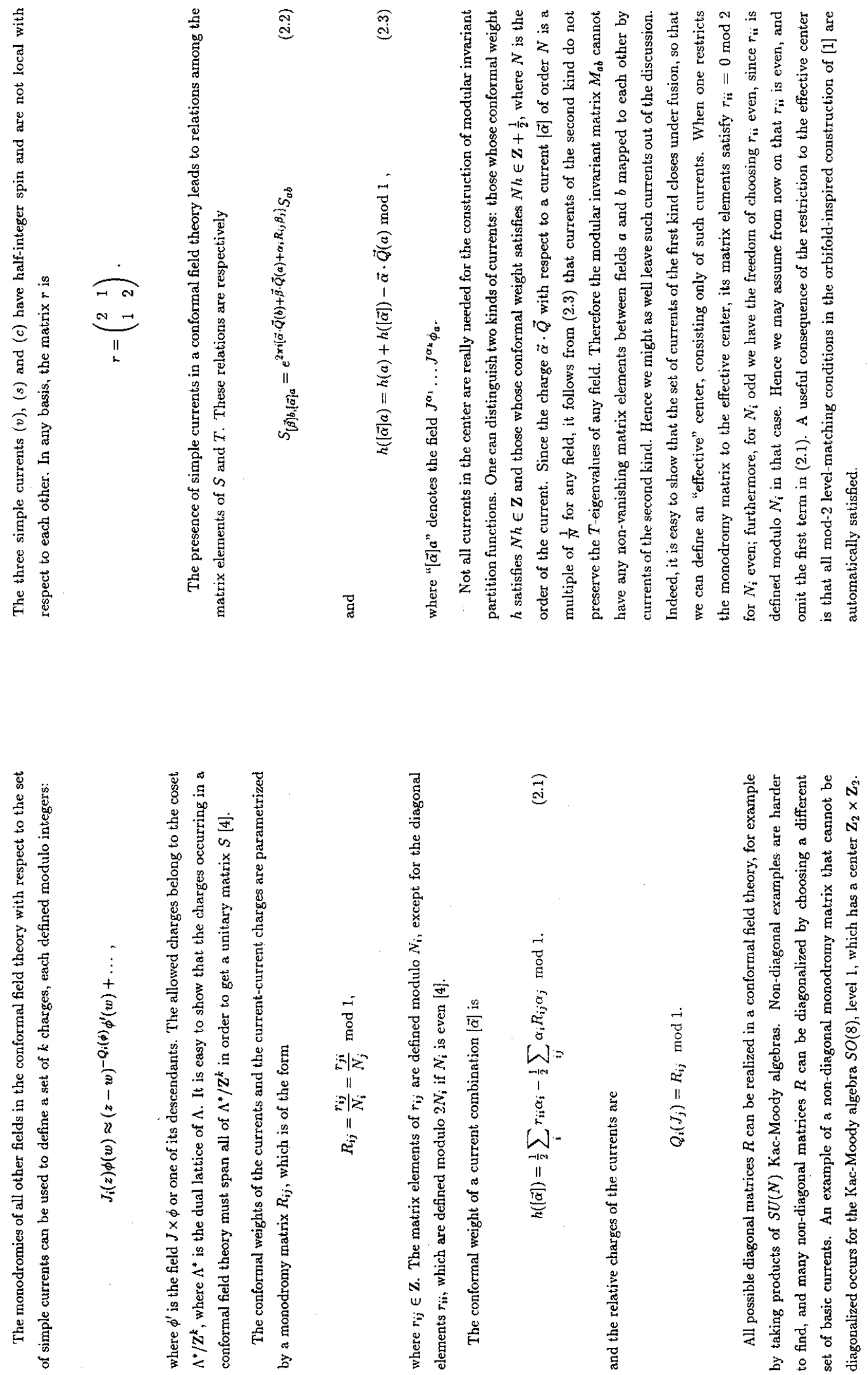


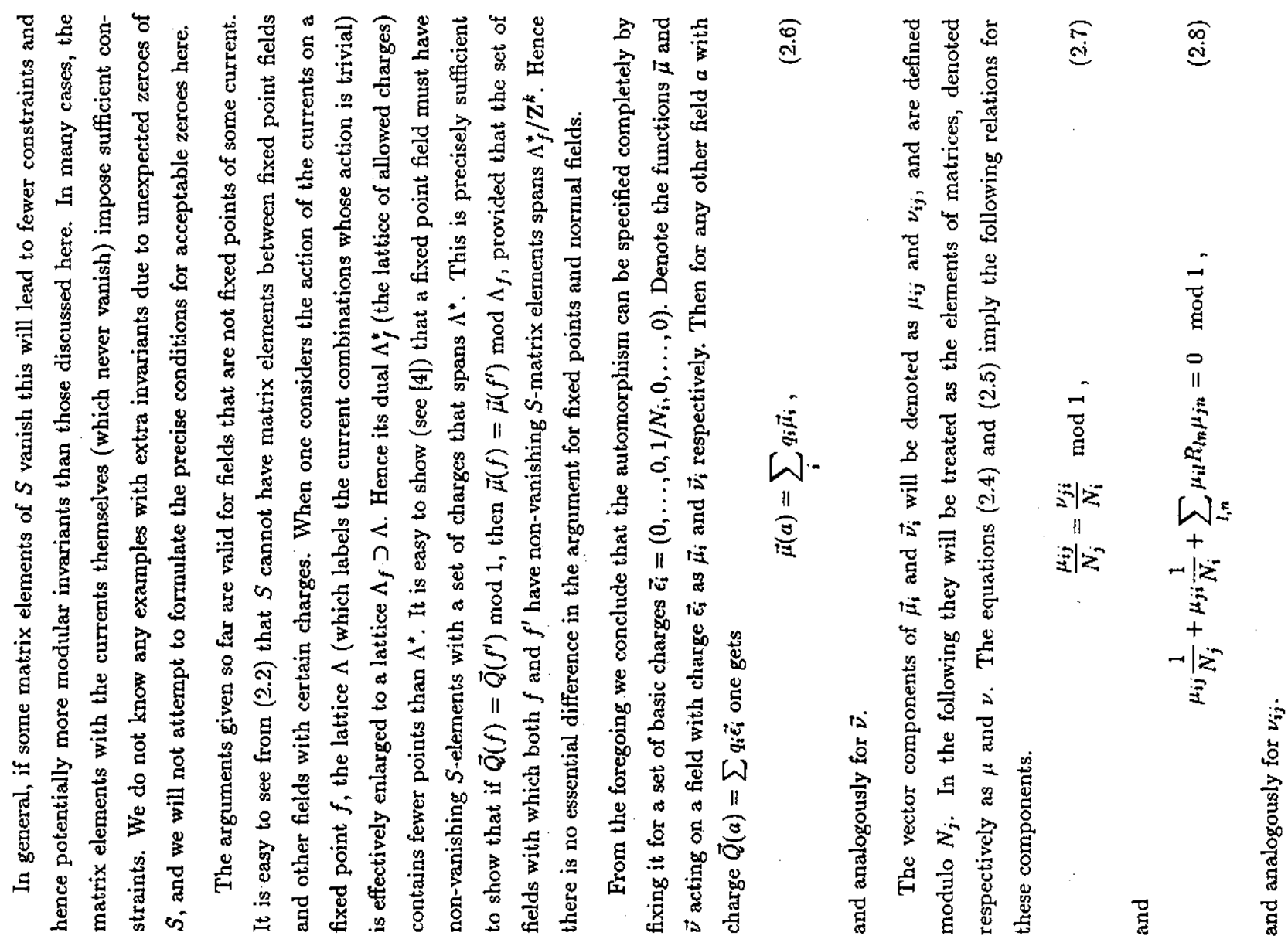

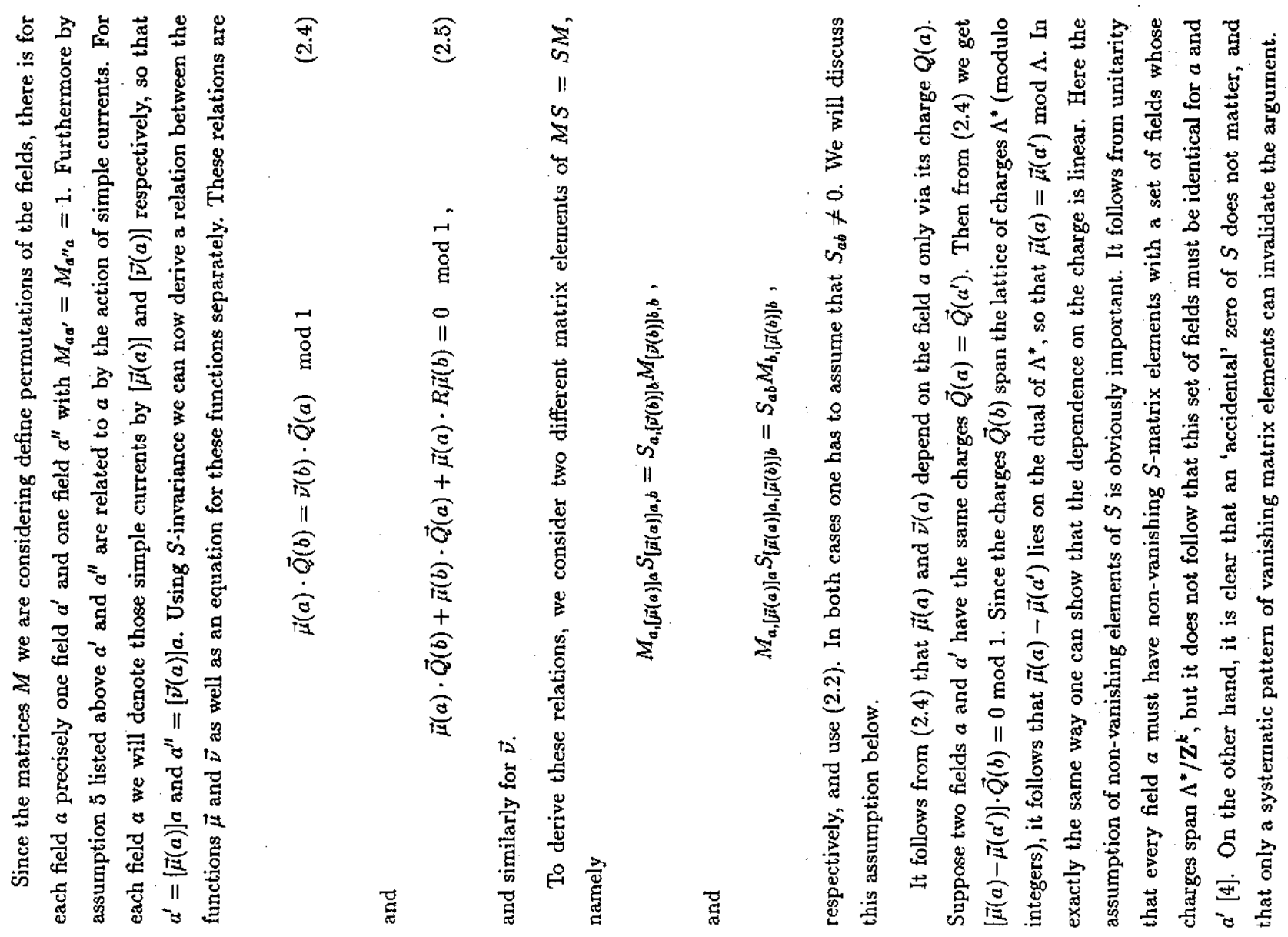



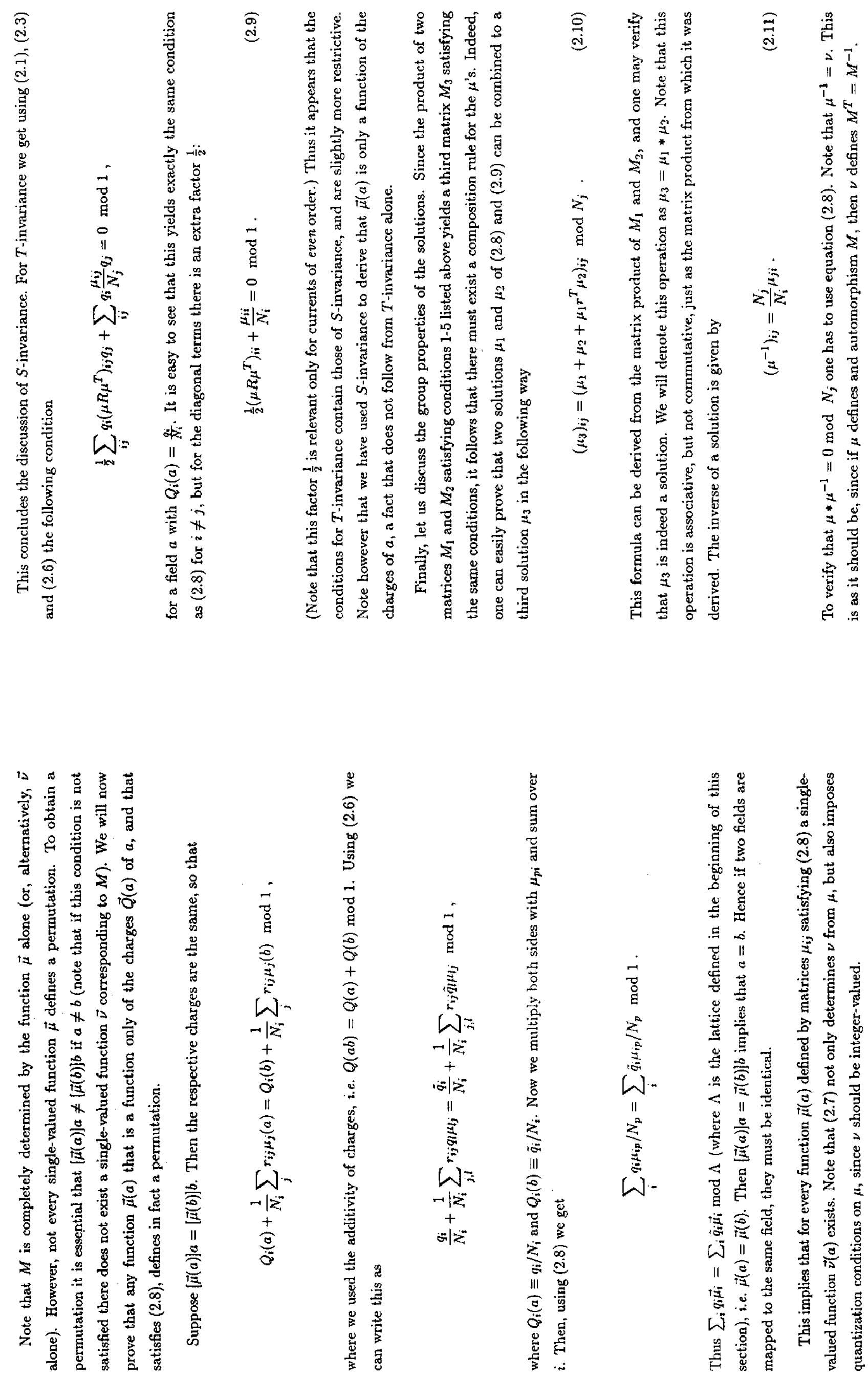

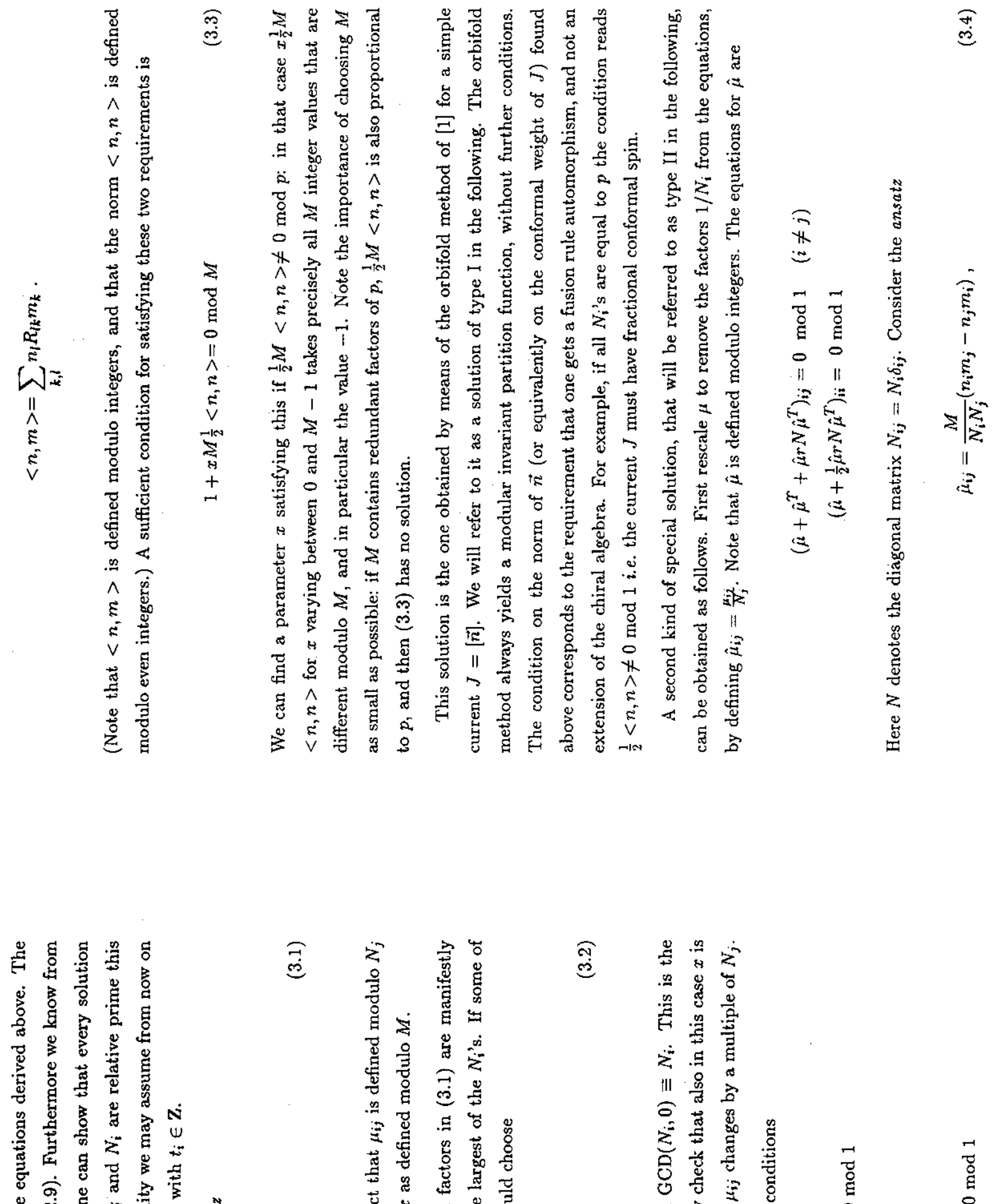

崫

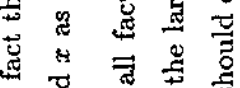

裹

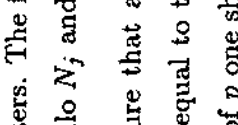

官

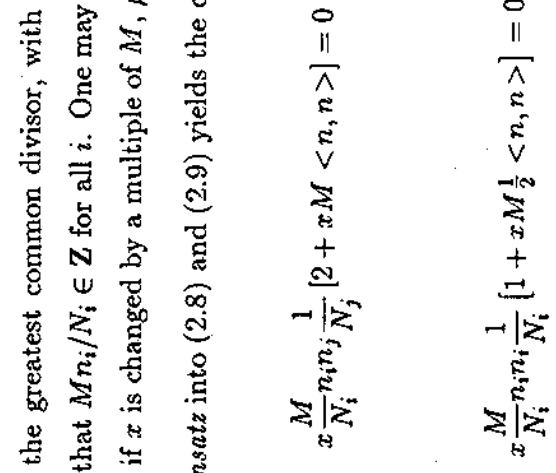

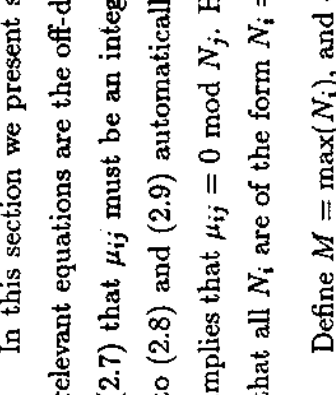

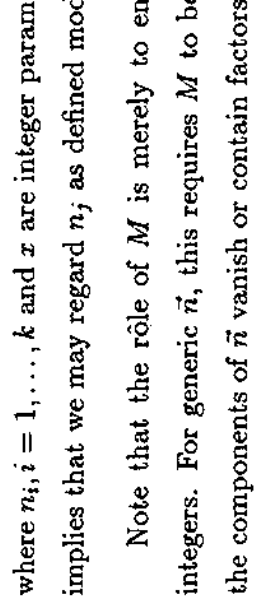

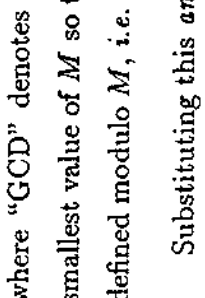

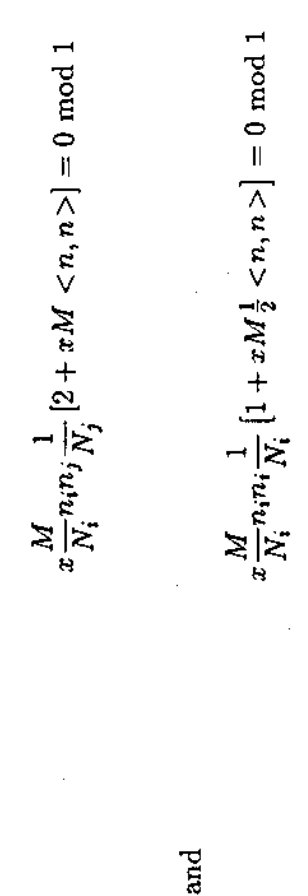



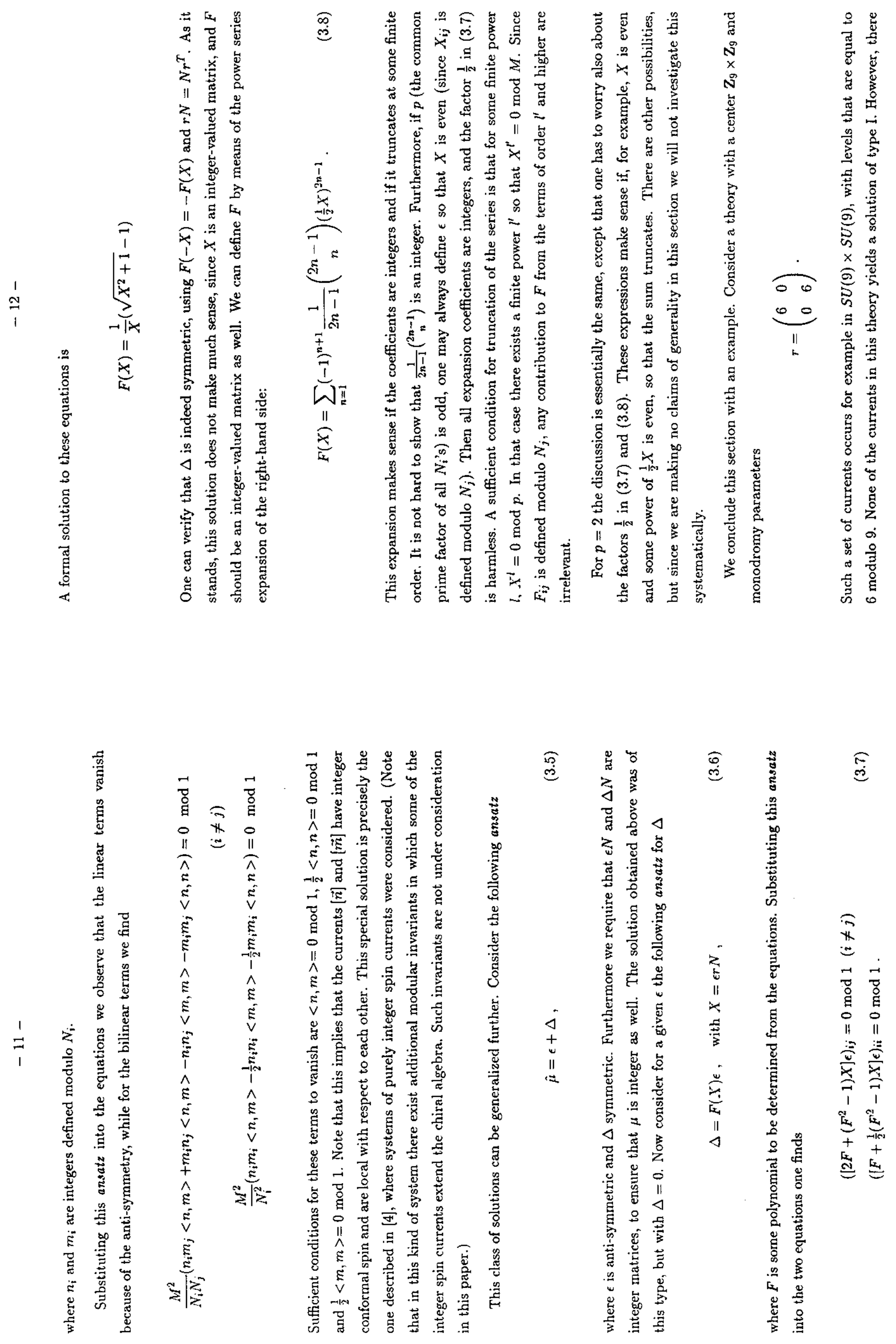


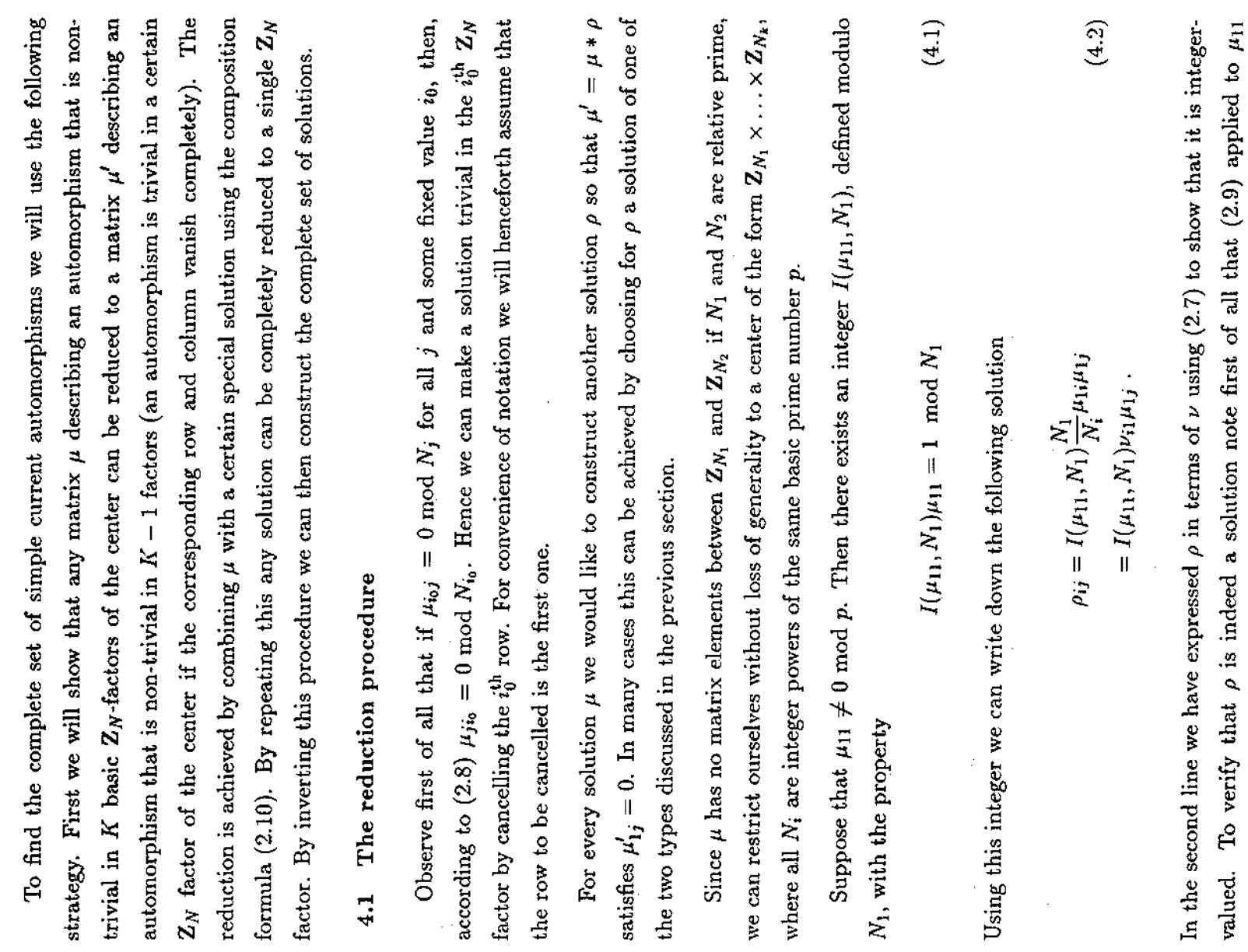

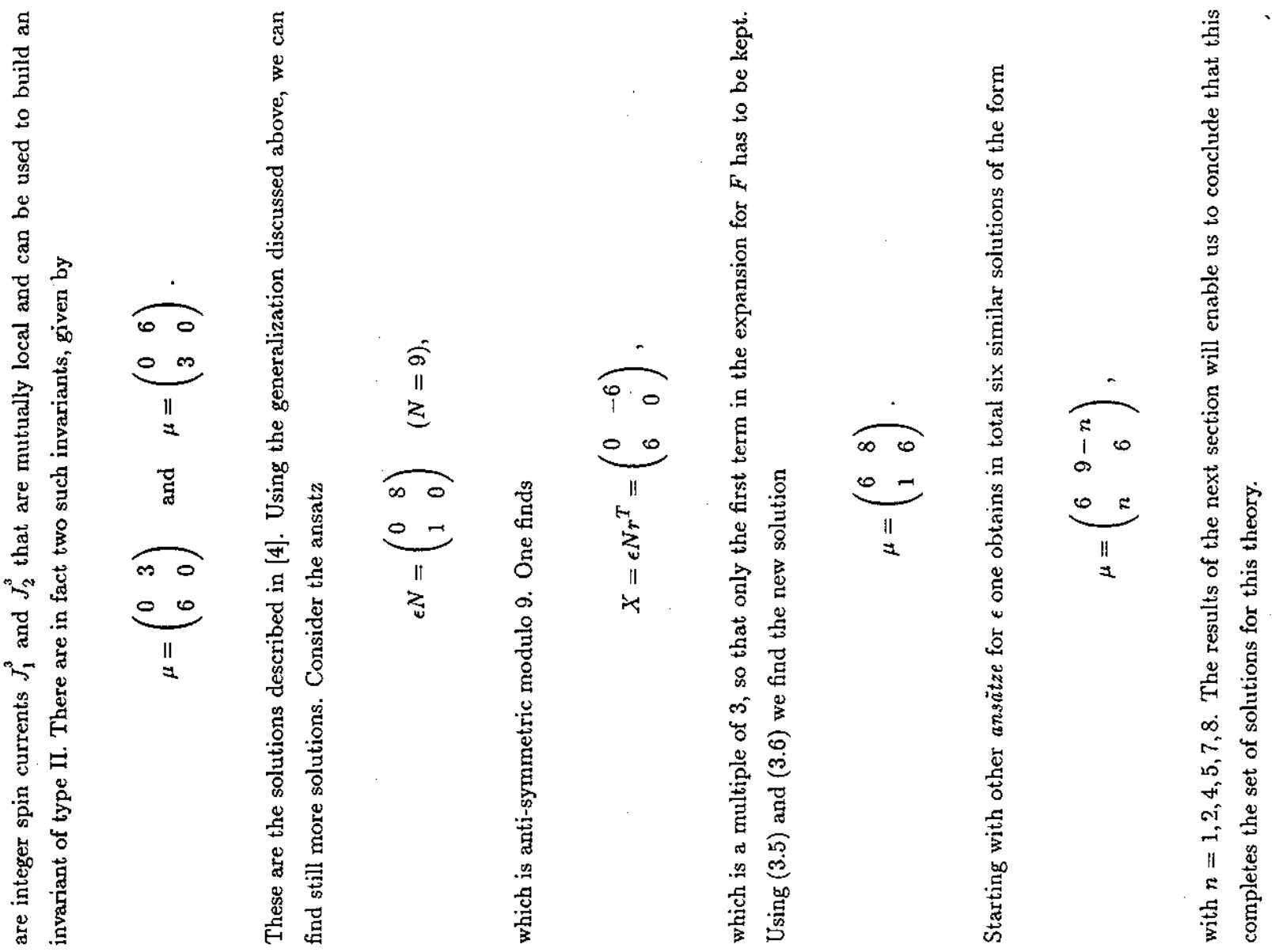




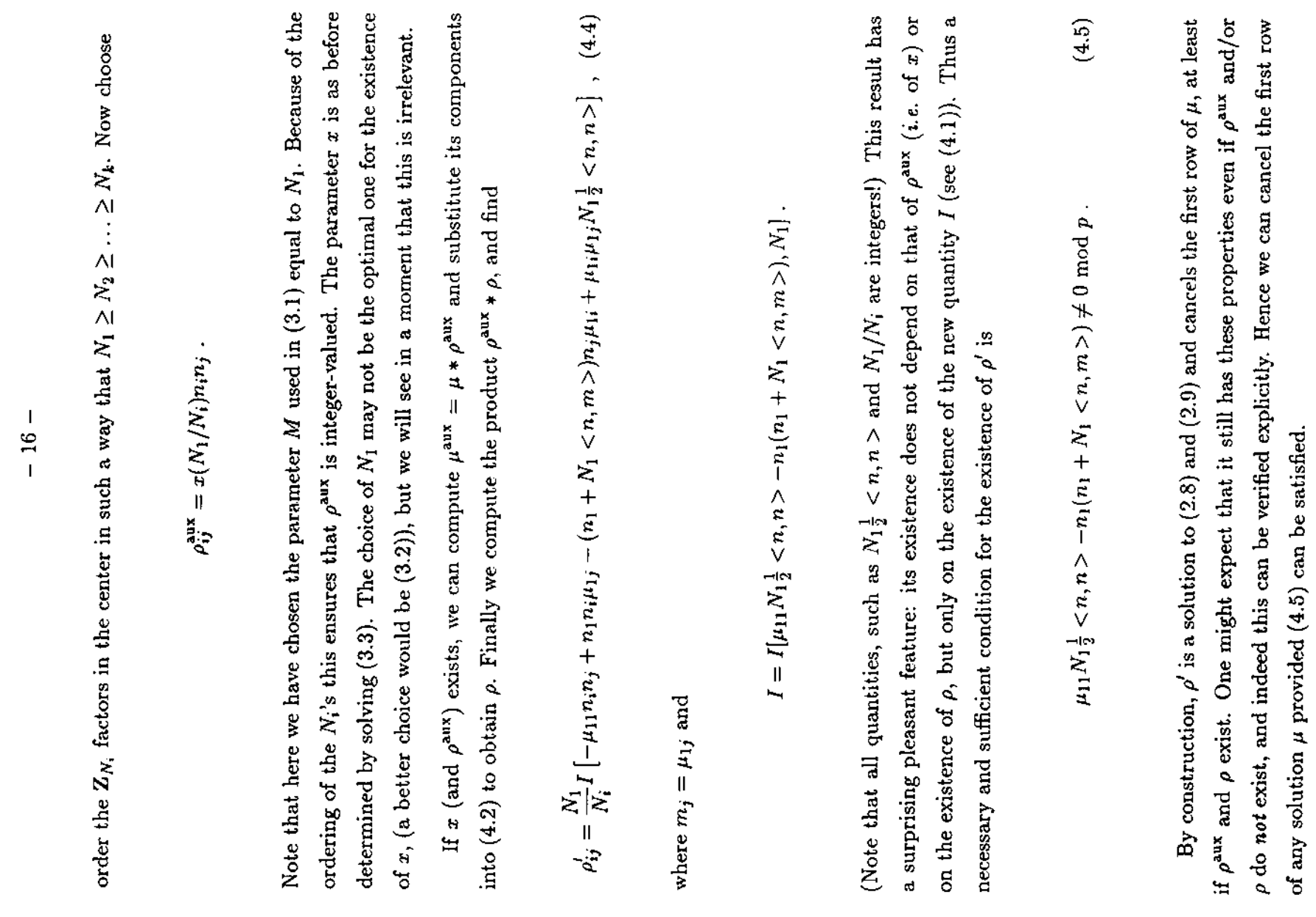

(1

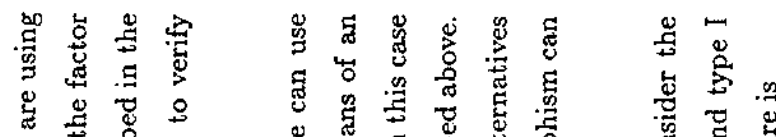

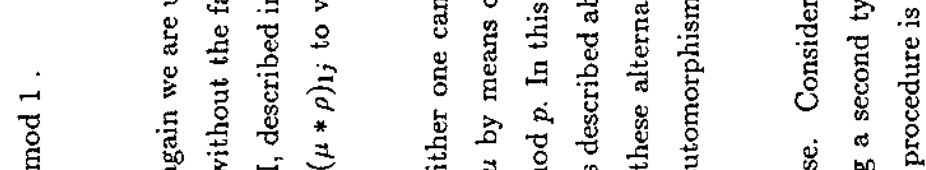

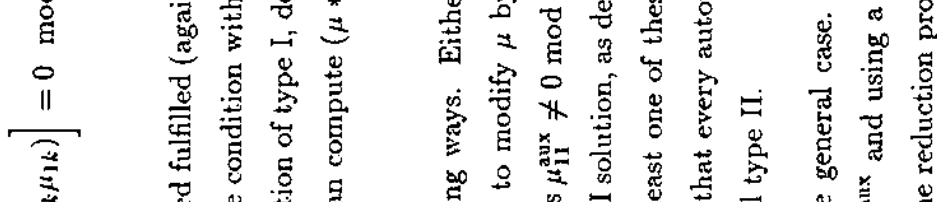

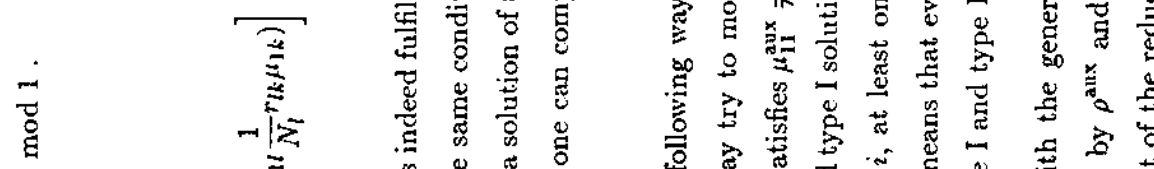

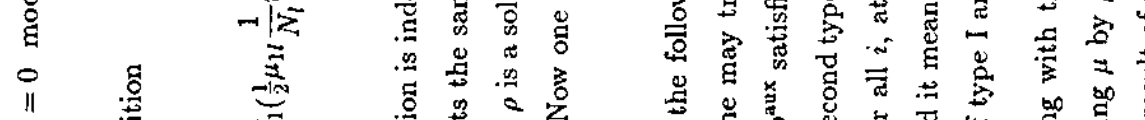

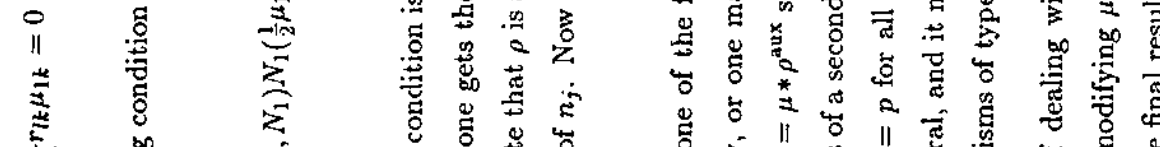

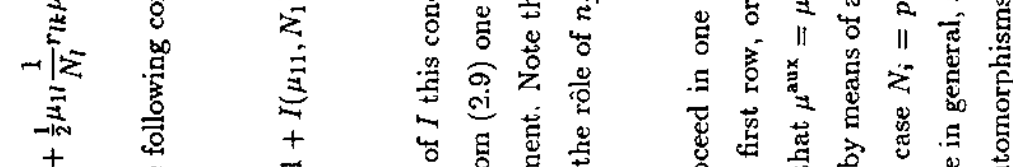

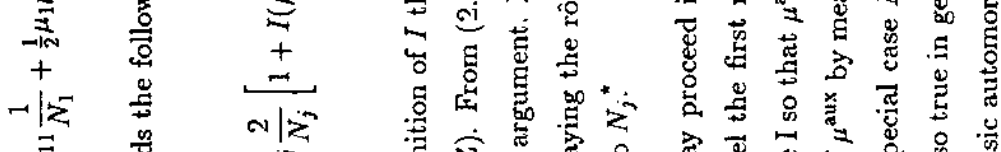

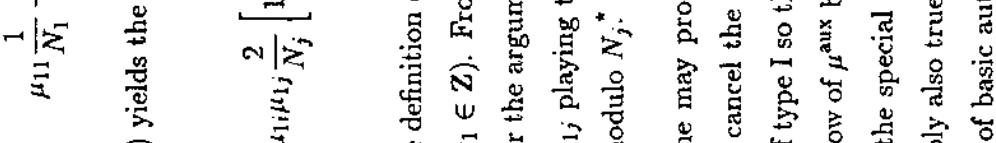

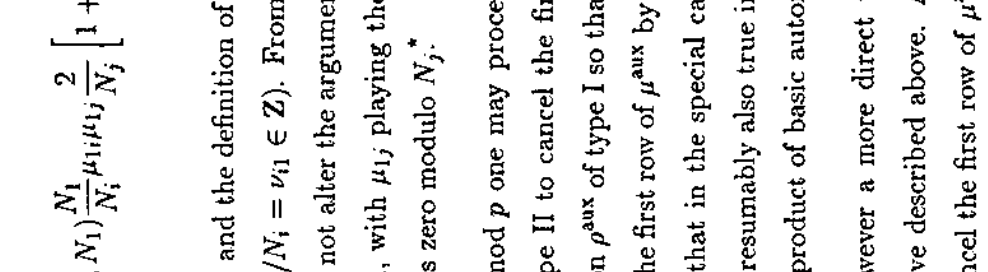

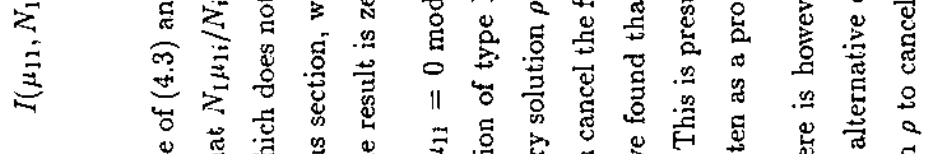

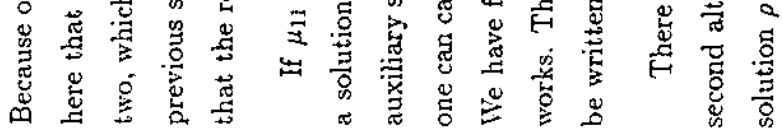

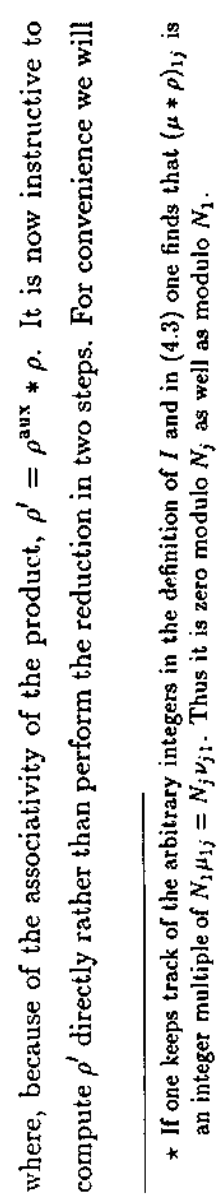




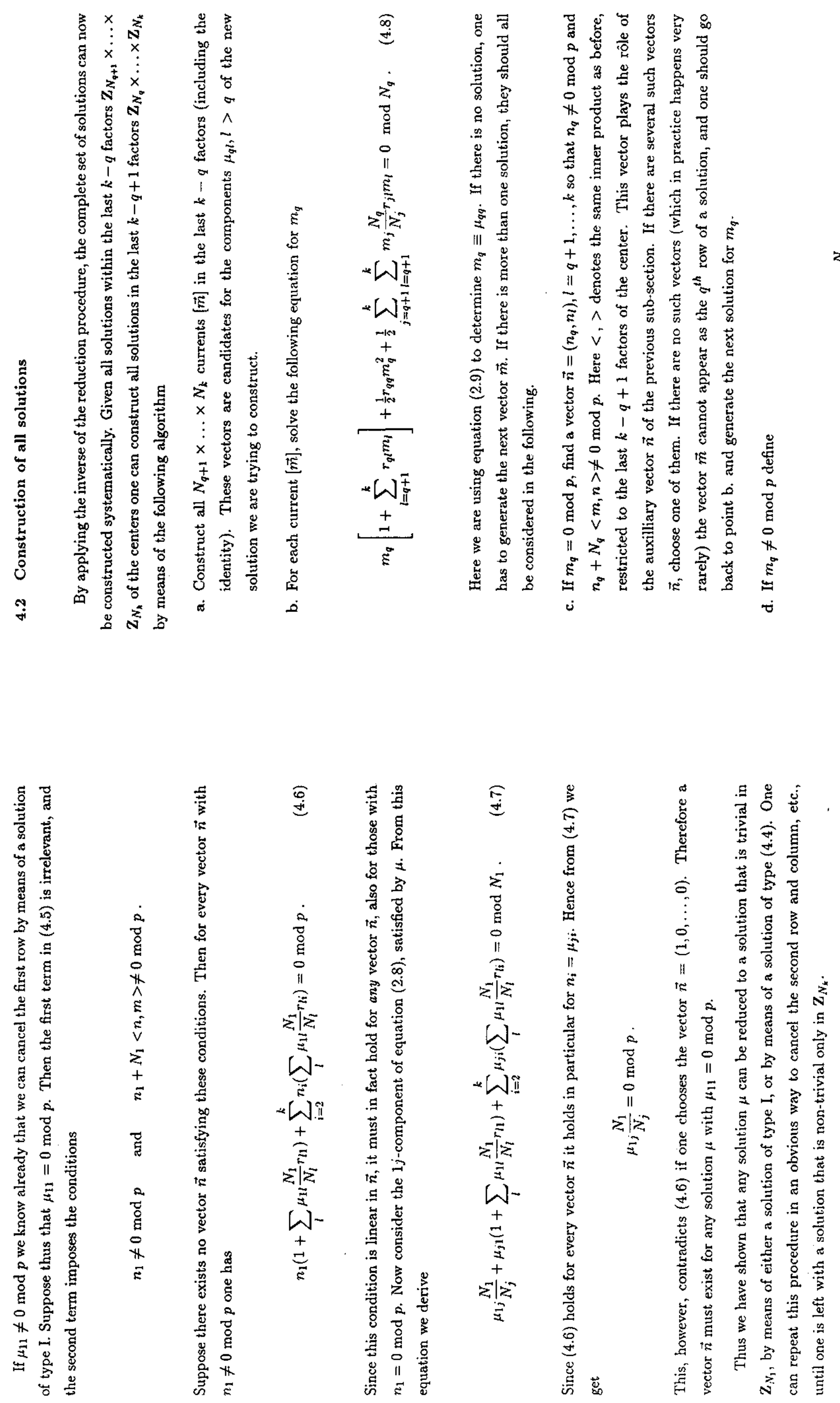




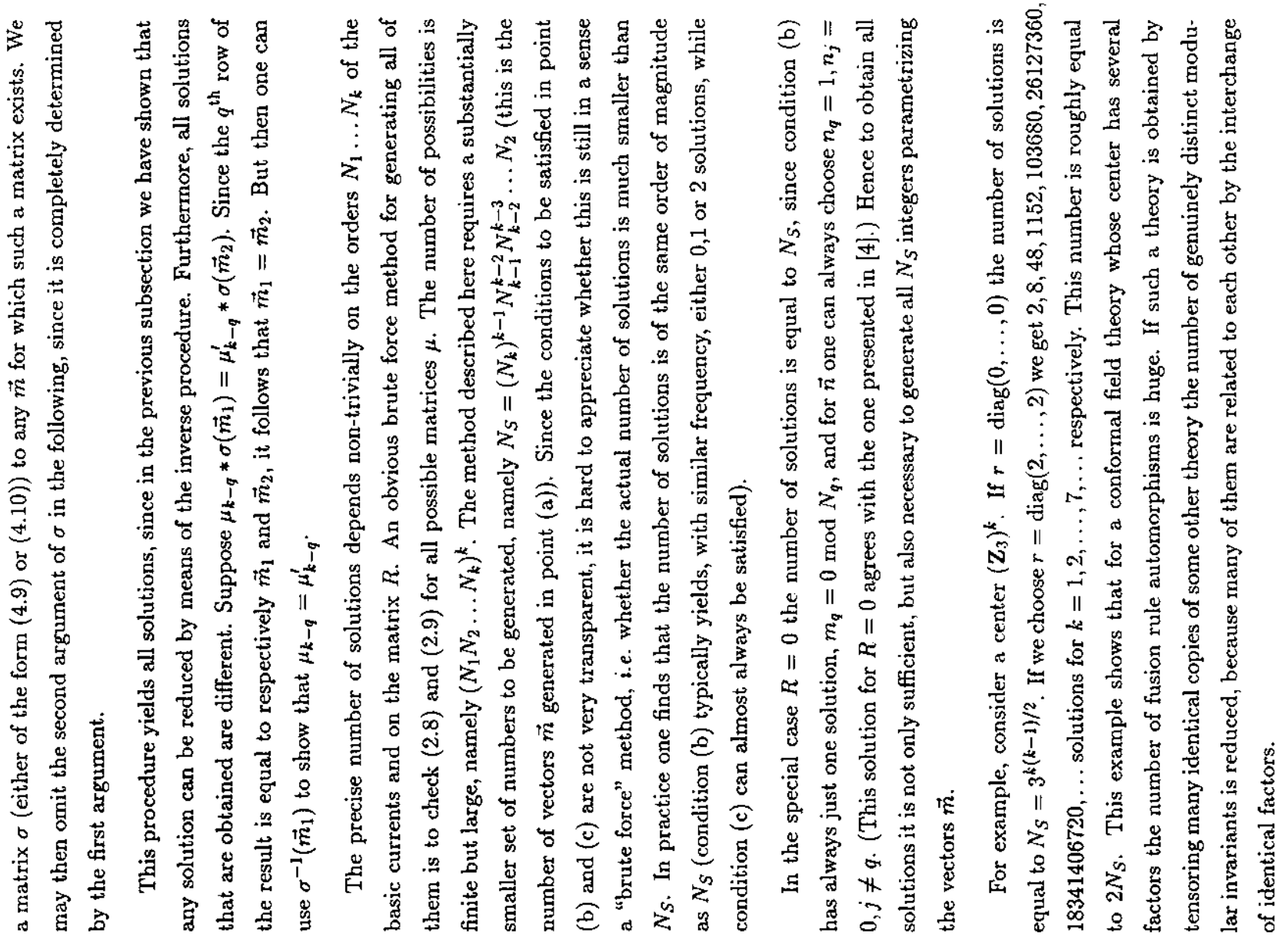

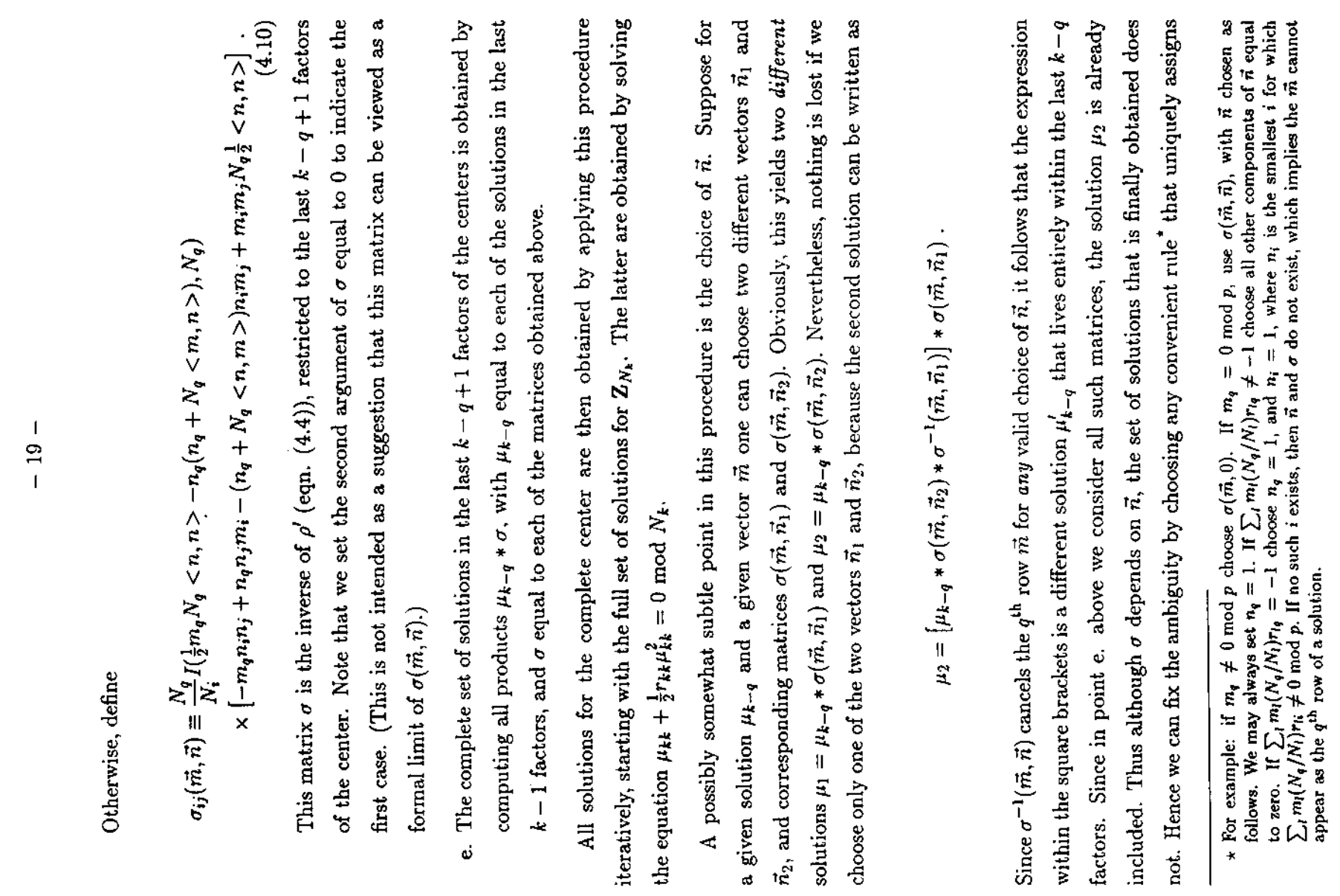


总

s.

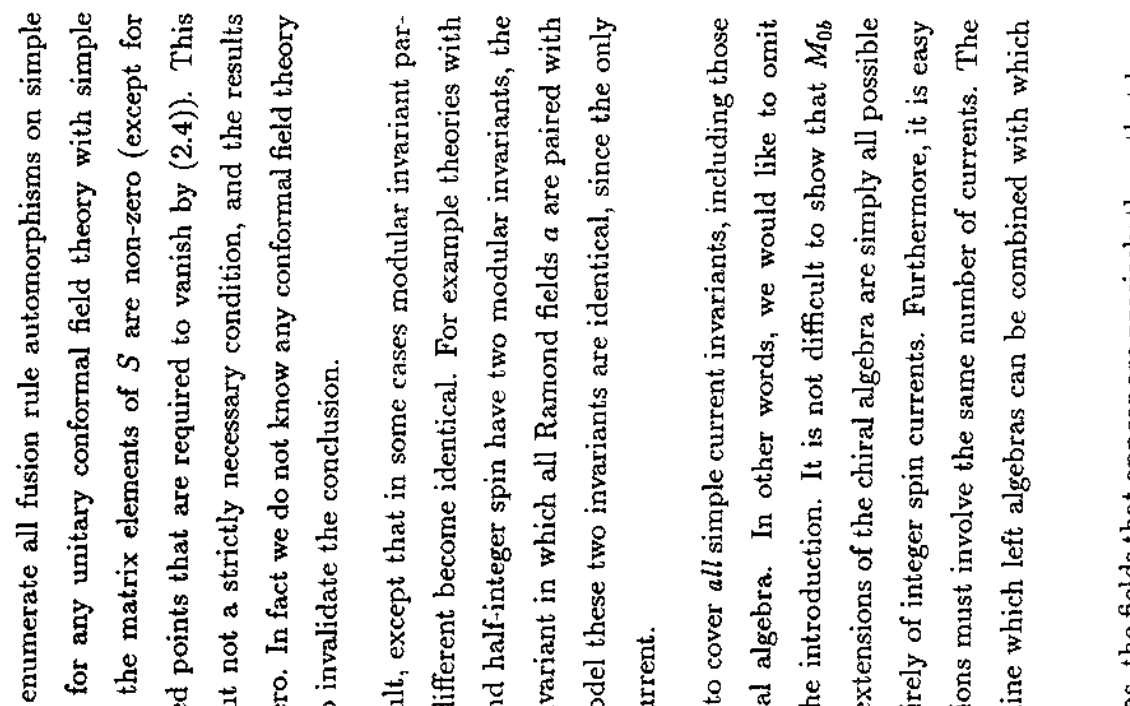

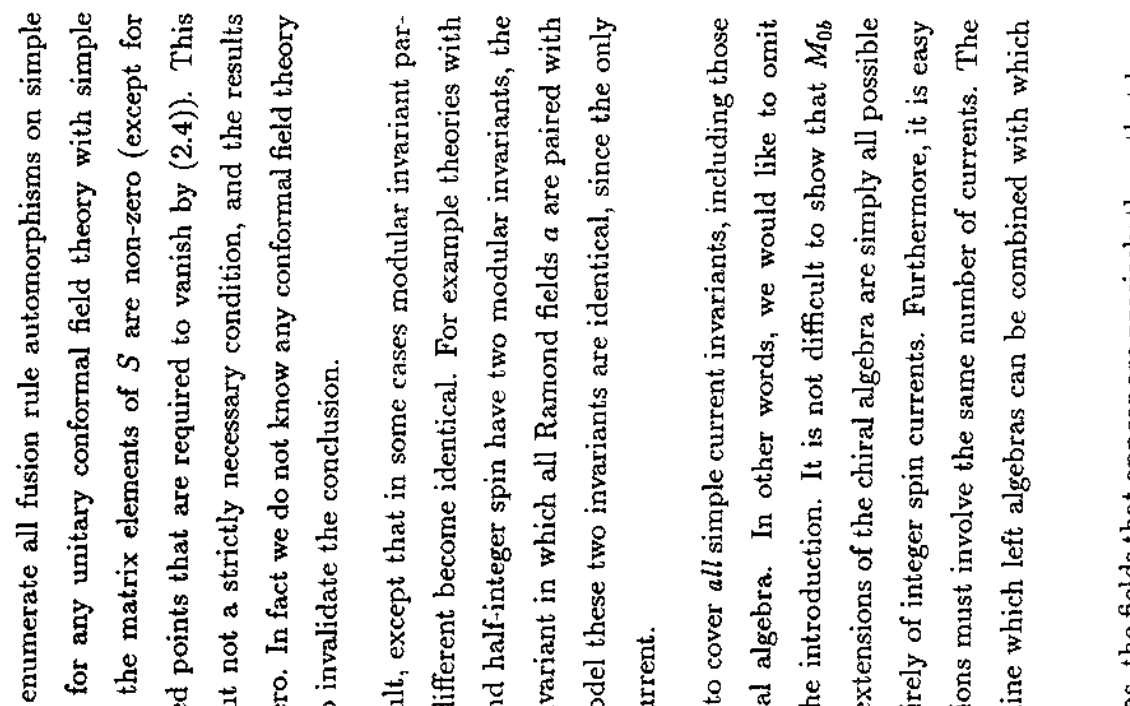

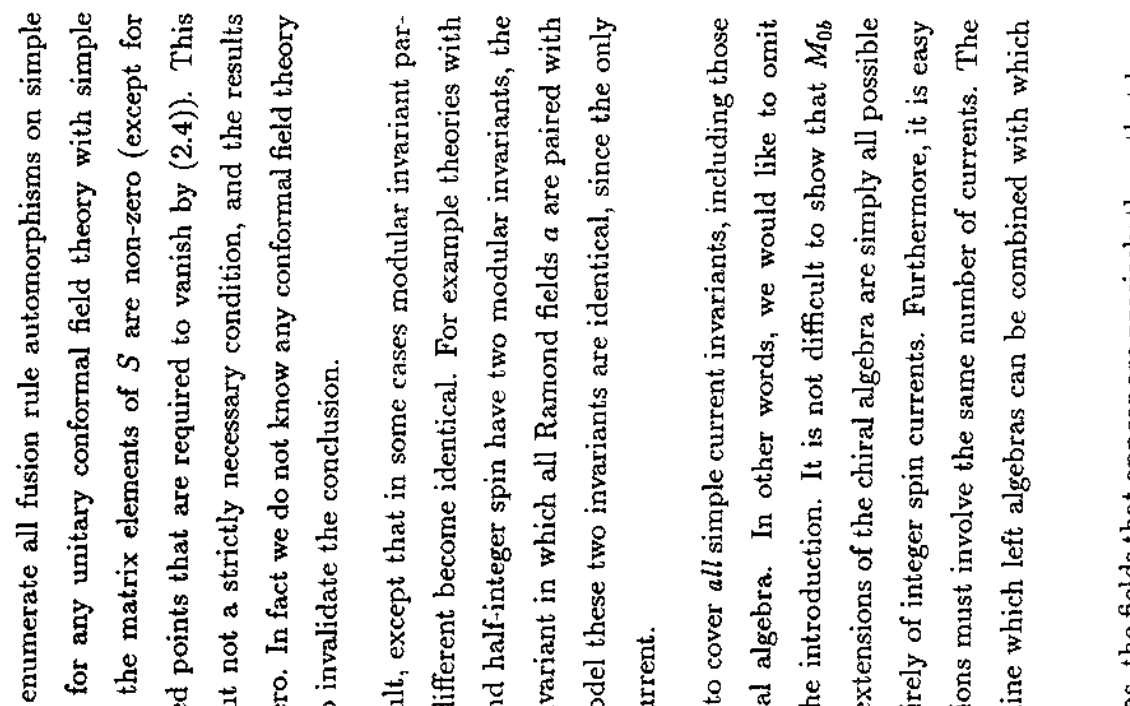

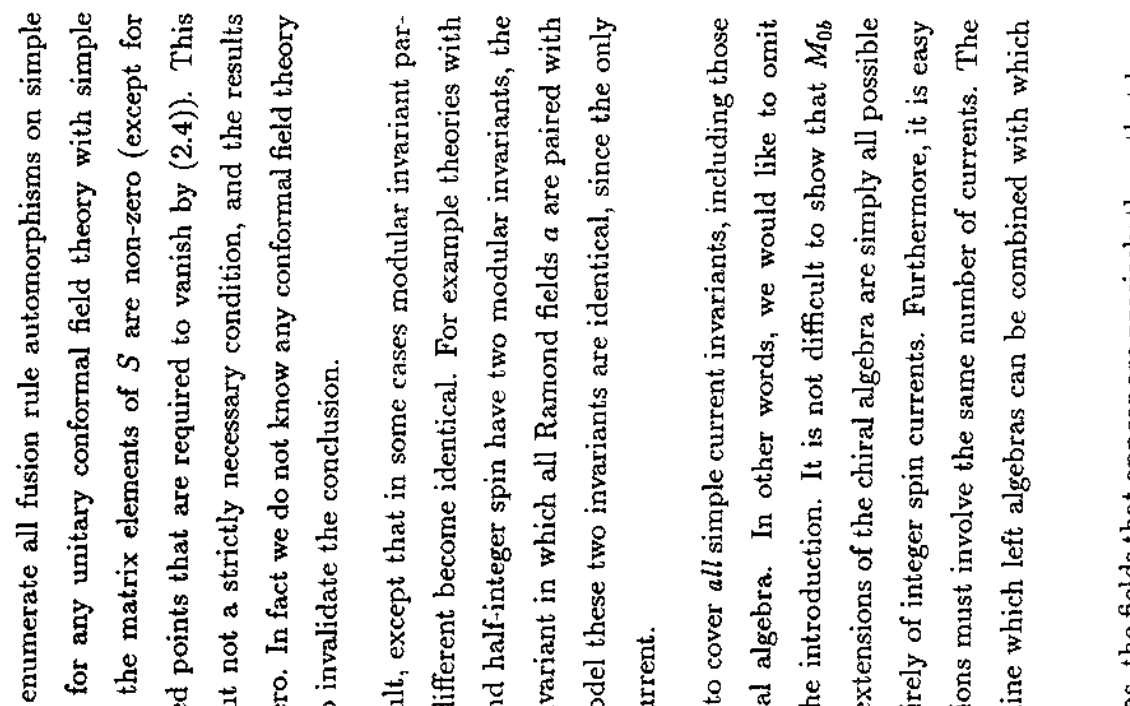

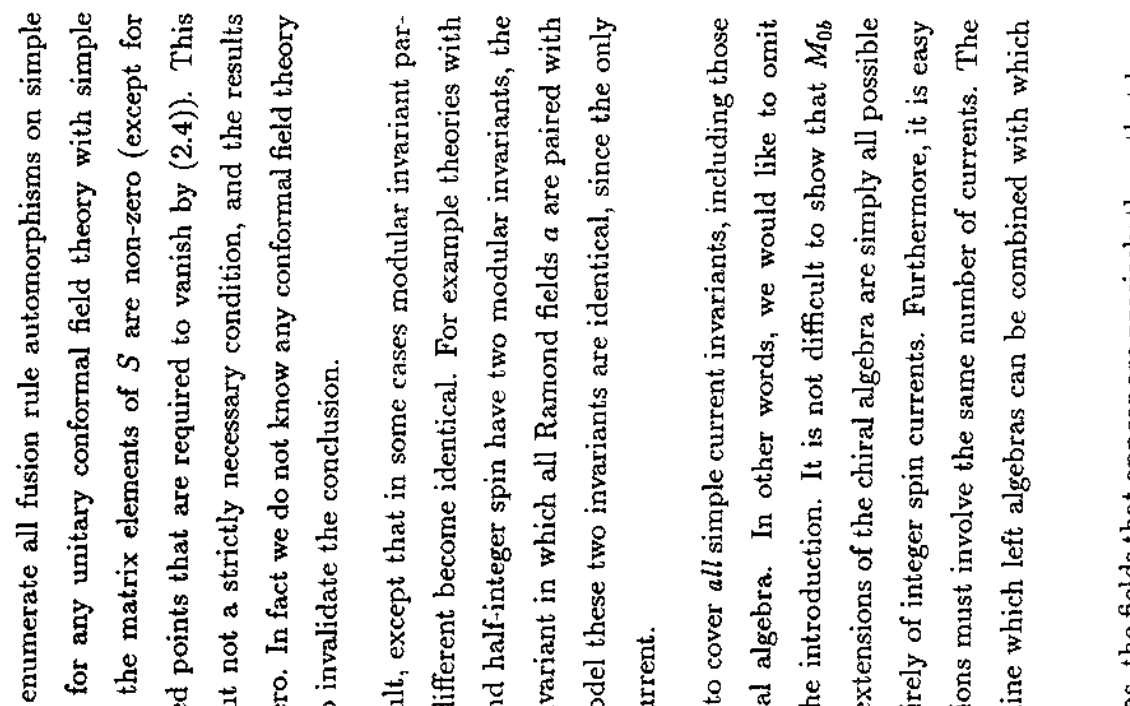

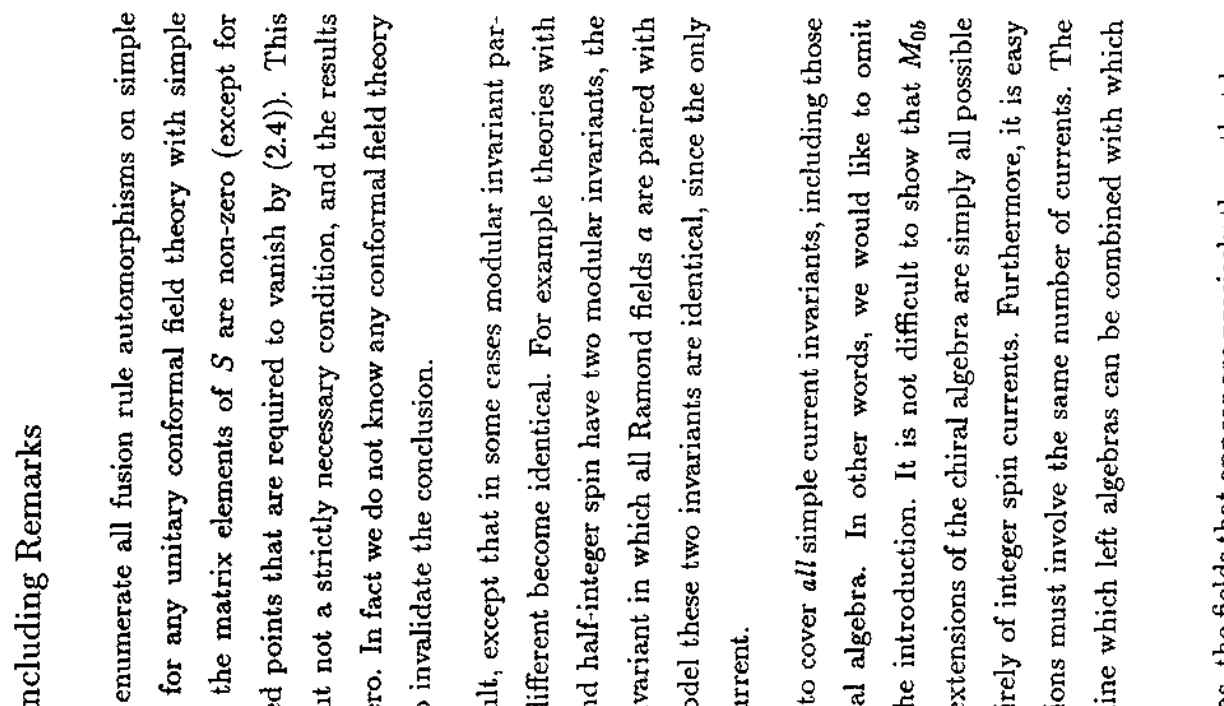

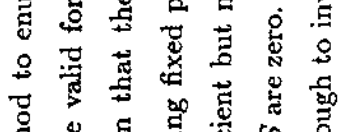

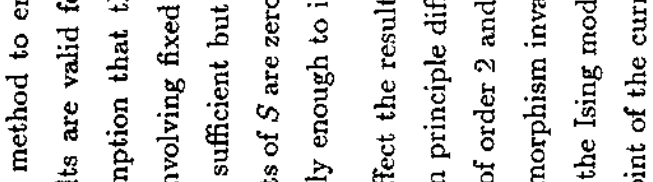

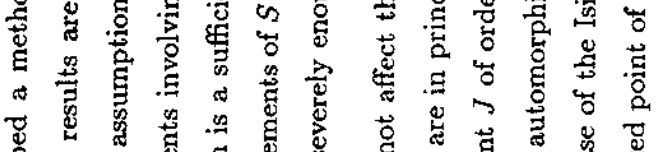

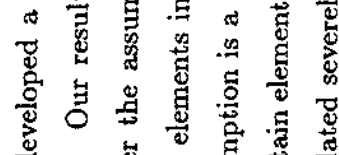

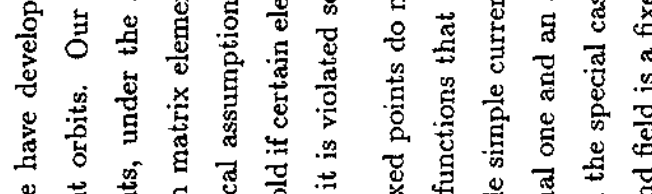

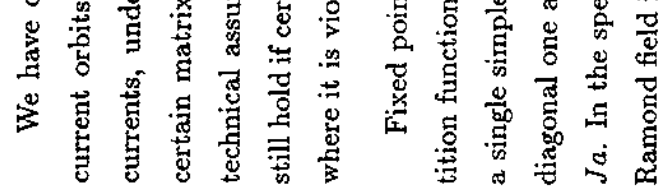

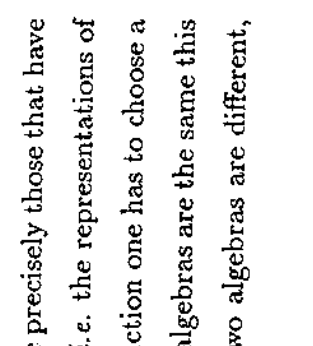

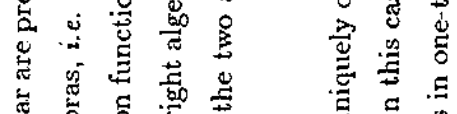

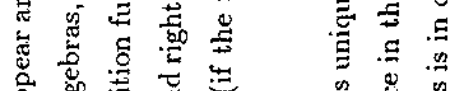

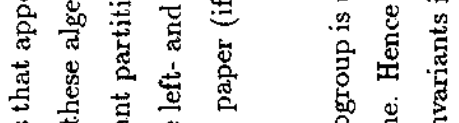

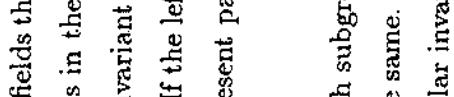

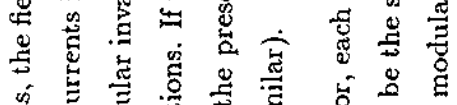

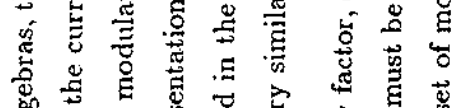

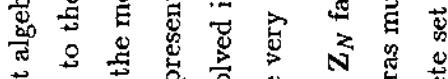

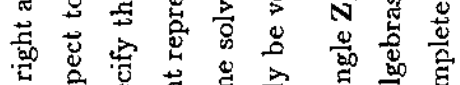

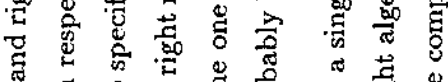

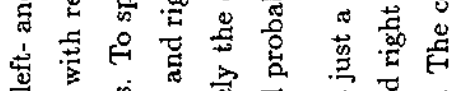

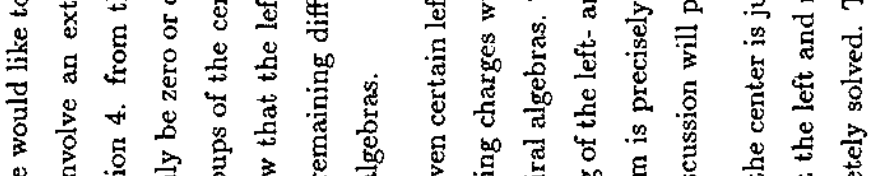

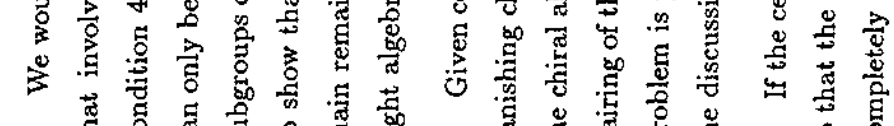

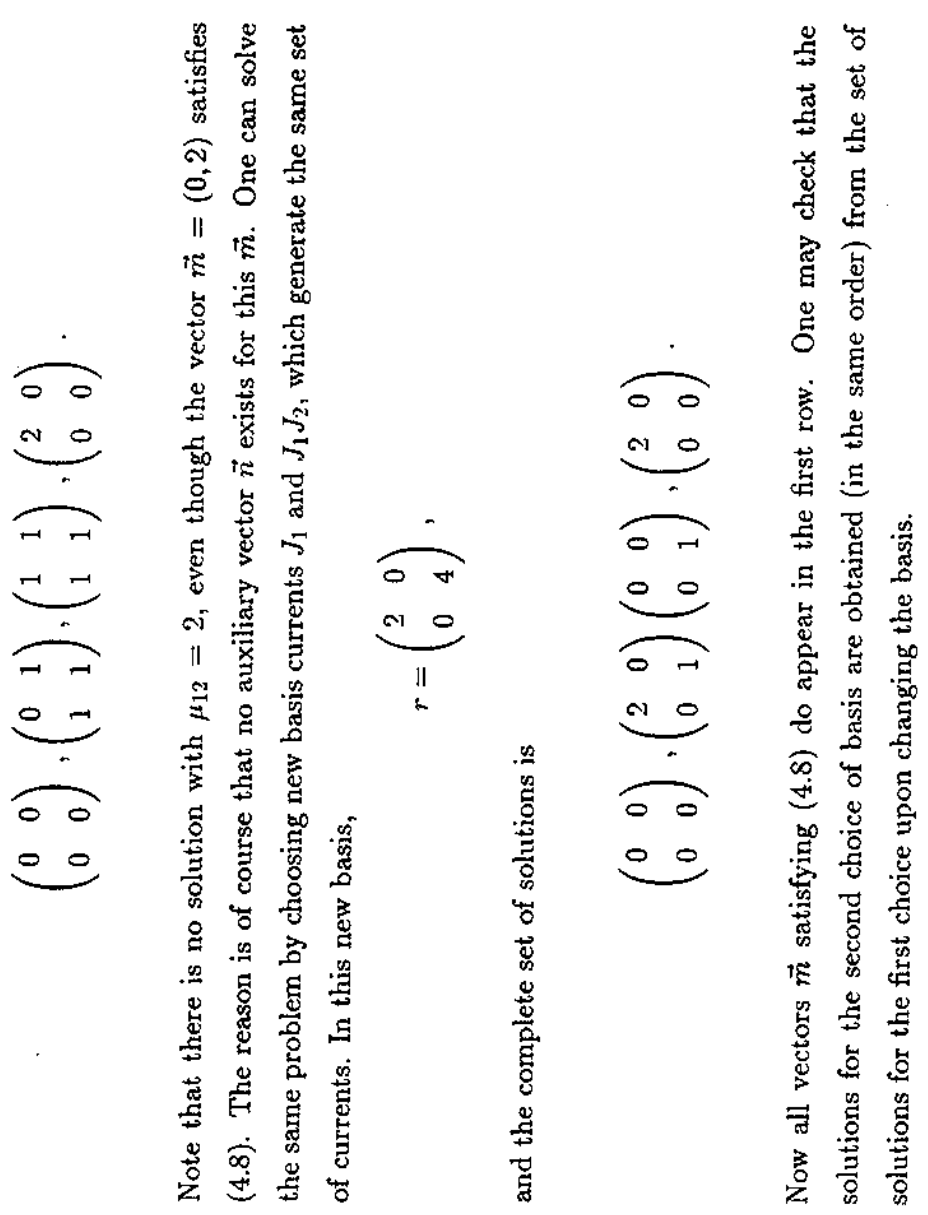




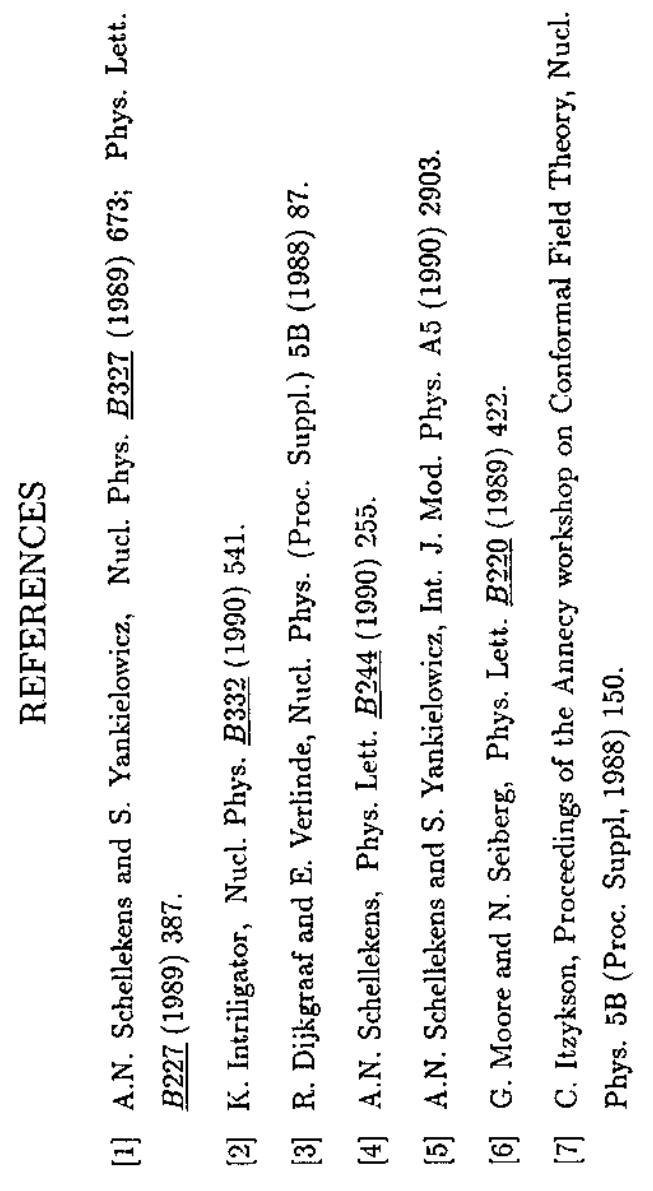

Imprimé au CERN. Prix : $0.40 \mathrm{Fr}$. 